\title{
Prebisch-Singer: debates, growth model and estimates
}

Citation for published version (APA):

Ziesemer, T. H. W., \& Mutz, C. (2005). Prebisch-Singer: debates, growth model and estimates. UNUMERIT, Maastricht Economic and Social Research and Training Centre on Innovation and Technology. MERIT-Infonomics Research Memorandum Series No. 008 https://doi.org/10.26481/umamer.2005008

Document status and date:

Published: 01/01/2005

DOI:

10.26481/umamer.2005008

Document Version:

Publisher's PDF, also known as Version of record

\section{Please check the document version of this publication:}

- A submitted manuscript is the version of the article upon submission and before peer-review. There can be important differences between the submitted version and the official published version of record.

People interested in the research are advised to contact the author for the final version of the publication, or visit the DOI to the publisher's website.

- The final author version and the galley proof are versions of the publication after peer review.

- The final published version features the final layout of the paper including the volume, issue and page numbers.

Link to publication

\footnotetext{
General rights rights.

- You may freely distribute the URL identifying the publication in the public portal. please follow below link for the End User Agreement:

www.umlib.nl/taverne-license

Take down policy

If you believe that this document breaches copyright please contact us at:

repository@maastrichtuniversity.nl

providing details and we will investigate your claim.
}

Copyright and moral rights for the publications made accessible in the public portal are retained by the authors and/or other copyright owners and it is a condition of accessing publications that users recognise and abide by the legal requirements associated with these

- Users may download and print one copy of any publication from the public portal for the purpose of private study or research.

- You may not further distribute the material or use it for any profit-making activity or commercial gain

If the publication is distributed under the terms of Article $25 \mathrm{fa}$ of the Dutch Copyright Act, indicated by the "Taverne" license above, 


\title{
MERIT-Infonomics Research Memorandum series
}

\author{
Prebisch-Singer: Debates, Growth Model \\ and Estimates
}

\section{Christine Mutz \& Thomas Ziesemer}

\section{5-008}

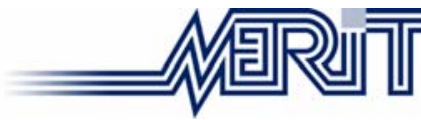

MERIT - Maastricht Economic Research Institute on Innovation and Technology

PO Box 616

6200 MD Maastricht

The Netherlands

T: +31433883875

F: +31433884905

http://www.merit.unimaas.nl e-mail:secr-merit@merit.unimaas.nl

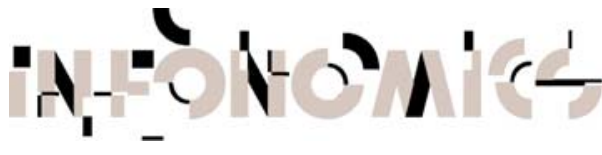

International Institute of Infonomics

c/o Maastricht University PO Box 616

6200 MD Maastricht

The Netherlands

T: +31 433883875

F: +31 453884905

http://www.infonomics.nl e-mail: secr@infonomics.nl 


\section{Prebisch-Singer: Debates, Growth Model and Estimates*}

Christine Mutz, Leipzig Graduate School of Management

Thomas Ziesemer, Maastricht University, Department of Economics and MERIT, P.O.Box 616, NL 6200 MD Maastricht. T.Ziesemer@algec.unimaas.nl

March 2005

\section{Introduction}

Prebisch and Singer (henceforth PS) have initiated several debates in economics, which have generated much research. Some of these debates may have converged to a compromise, whereas others are much less researched. We briefly summarize them in the next section in order to point out that the implications for growth theory have been largely neglected. Then we will present a growth model and estimate which show that income and price elasticities matter for long-run growth.

\section{The debates}

The evidence of falling terms of trade of developing countries' primary commodities relative to British manufactures presented in Prebisch (1950) based on Singer's UN report has led to a huge literature trying to clarify the question whether or not the terms of trade are falling. New data sets and some new econometric techniques related to the question have stimulated a new round of the debate. The compromise as it appears in textbooks nowadays (see Perkins et al. 2001) is that the terms of trade of developing countries are increasing if oil is included but decreasing if oil is excluded. All other results are due to limitations of the number of countries, years or goods.

A second debate focussed on the question whether falling terms of trade are necessarily a bad thing. Relative price movements are not uniquely linked to the development of welfare and indeed in many models related to Prebisch-Singer ideas welfare increases when the terms-of-trade fall (see Ziesemer 1995 for a broad discussion of the literature). Kravis (1970) argued that falling terms of trade mainly reflect technical progress and then a

\footnotetext{
${ }^{*}$ Paper prepared for the Festschrift on the occasion of the $95^{\text {th }}$ birthday of Professor Sir Hans Singer
} 
fall in the terms of trade just reflects an improved market position. However, with technical progress largely absent in developing countries it was held to be more likely (see Prebisch 1959) that the terms of trade fall because of low income elasticities of demand for developing countries' exports (not necessarily only in commodities). This idea is mostly presented nowadays under 'Engel's law'. For the past the argument is compelling. In the future the classical argument of scarce natural resources may gain momentum relative to the fall in demand.

With Engel-Prebisch type of market forces shifting production from the primary to the secondary sector the question then was whether or not the governments in developing countries should reinforce this shift by means of import substituting industrialization or allow for mitigation in the sense of developing countries specializing on goods that have lower income elasticities of demand. This link between growth, trade and industrial policy was not looked at in a comprehensive way for quite some time. The free traders considered only static efficiency of general equilibrium models. The protagonists of infant-industry policies focussed on increasing returns models at the firm level. Evidence is crucial and turned out to be about this: when the infant was bravely going to school and enhanced productivity of domestic industries in the time of its protection, ISI was a useful contribution to development, mainly in East-Asia. However, when schooling was neglected, as it was for a long time due to the tax resistance of Latin American countries, and ISI effectively protected backward technology, it was inefficient and the dynamic gains hoped for were not achieved. In short, all arguments of both sides are important but the policy packages were not complete in any country.

According to economic theory the protection of infant industries should be done through tariffs only if credits and subsidies are not available. With imperfect domestic credit markets and tax resistance though, the alternative was to use tariffs or abandon the ISI all together. A natural question then is whether or not foreign capital can be used to support the infant industry. Singer (1950) raised the question how the potential gains might be distributed between borrowing and lending countries. Recent research has shown that there may be two deviations from the Walrasian equilibrium. First, Eaton and Gersovitz (1981) found that credit market disequilibrium existed for many countries before 1974. The credit volume is lower and the interest rate is larger than in Walrasian equilibrium. Second, there is some evidence of loan pushing (see Darity 1986). Basu (1991) has provided a model for this. Under loan pushing developing countries get more credit then in Walrasian equilibrium but they pay interest rates which move all the advantages to the creditor and the debtor country down to its 
autarkic reservation utility. Ziesemer (1997) then showed that interest shocks, such as in the crises of the 1930s and the 1980s, may move an economy from Basu's loan pushing equilibrium to one of credit rationing. Debt crises mostly occur in countries with fixed and overvalued exchange rates. Speculative attacks are provoked by this. They enforce, among many other things, devaluations. As devaluations are to some extent real (Bahmani-Oskooee, M. and M. Miteza 2002) this again raises the question of the size of price elasticities of export demand.

The topics discussed above have been widely discussed. The relation between growth and the Prebisch-Singer arguments has been researched much less. Prebisch (1950, p.2) emphasized that imported capital goods are at the heart of the matter because they make developing countries dependent on the exports to developed countries where they earn the money to pay for the machines. With falling terms of trade there must be a special role for the price elasticity of export demand, unless the small country assumption applies. As the fall in the terms of trade is caused by low income elasticity, the incorporation of the arguments of Prebisch and Singer into a growth model requires a model with imported capital goods and an export demand function with income and price elasticities of export demand. Bardhan and Lewis (1970) provided a model with imported capital goods and a price elasticity of export demand related to the two-gap literature. Ziesemer (1995) made the role of the income elasticity of export demand and technical progress explicit and related the model to the literature dealing with the ideas of Prebisch and Singer. ${ }^{1}$ In this paper we reproduce the model and an estimate of that model from Mutz and Ziesemer (2005) in order to show that the income and price elasticities of export demand do indeed matter for growth.

\section{The Model}

The question dealt with in this section is whether imports of capital goods and low (high) export demand elasticities could account for slow (fast) growth in comparison with the Solow (1956) growth model. The model assumes flexible wages and exogenous employment. A Cobb-Douglas production function with constant returns to scale, an assumption that will be relaxed and tested in the estimates (see also Mutz and Ziesemer 2005), and exogenous technical progress is used:

\footnotetext{
${ }^{1}$ An extension to perfect capital movements can be found in Ziesemer (1995b) and to imperfect capital movements in Ziesemer (1998).
} 


$$
Y=e^{b t} K^{\beta} L^{1-\beta}, \hat{Y}=b+\beta \hat{K}+(1-\beta) \hat{L},
$$

$Y$ denotes output, $K$ capital, $L$ labour, $b$ the rate of technological progress and $\beta$ the elasticity of production of capital. Taking logs and derivatives on both sides with respect to time shows how the growth rate of output relates to the growth rate of inputs. A "hat" over a variable indicates a growth rate. Labour is assumed to grow at rate $\varepsilon$, which is determined exogenously:

$$
L(t)=L(0) e^{\varepsilon t}, \hat{L}=\varepsilon
$$

The fact that they are importers of capital goods seems to be a fundamental problem of developing countries. This point is found throughout Prebisch's papers (see Prebisch 1950, p.2). He thought that importing less luxury consumption goods could solve the issue. Although this may be helpful, it cannot be a solution by itself. Therefore, it is assumed that no luxury items are imported. Problems referring to the terms of trade or growth may occur despite this postulated solution. Fundamental obstacles for developing economies are rather the importation of capital goods as well as limited export demand. By assumption, capital goods invested in developing countries must be imported:

$$
M=\dot{K}
$$

A "dot" over a variable denotes its derivative with respect to time, and $M$ represents imports. Capital goods are the only imports - another simplification besides the absence of foreign debt - and have to be paid for by exports. This requirement stems from the trade-balance equilibrium. Investments are, therefore, limited by exports, denoted by $X$, which are expressed in terms of the imported capital goods:

$$
\hat{K}=\frac{\dot{K}}{K}=p \frac{X}{K}, \hat{\hat{K}}=\hat{p}+\hat{X}-\hat{K}
$$

$p$ represents the terms of trade, defined as the price of domestic goods in terms of imported capital goods. Investments need to be paid for by domestic savings measured in terms of imported capital goods. The savings rate $s$ is assumed to be a constant proportion of output in this theoretical part: 


$$
\hat{K}=\frac{\dot{K}}{K}=s p \frac{Y}{K}, \hat{\hat{K}}=\hat{p}+\hat{Y}-\hat{K}
$$

Investments are limited by exports. Exports in turn are assumed to depend on the trade partners' income, $Z$, and on the terms of trade. For the sake of simplicity, a log-linear export function is used:

$$
X=Z^{\rho} p^{\eta}, \hat{X}=\rho \hat{Z}+\eta \hat{p}
$$

$\rho$ denotes the income elasticity and $\eta$ represents the (negative) price elasticity of export demand. The usual approach of equating the marginal productivity to the interest rate in order to maximize profits in competitive markets yields:

$$
\begin{aligned}
& r=p e^{b t} \beta K^{\beta-1} L^{1-\beta}, \hat{r}=\hat{p}+b+(\beta-1)(\hat{K}-\hat{L}), \\
& w=p e^{b t} K^{\beta}(1-\beta) L^{-\beta}, \hat{w}=\hat{p}+b+\beta(\hat{K}-\hat{L}),
\end{aligned}
$$

Here, $w$ stands for the real wage rate expressed in terms of foreign goods; $w / p$ means the real wage rate measured in units of domestic goods. Together, these eight equations explain the eight variables $Y, L, M, p, K, X, w$, and $r$.

Plugging the growth rates of exports and output into the export and saving constraint for investment, respectively, gives:

$$
\begin{aligned}
& \hat{\hat{K}}=\hat{p}+\rho \hat{Z}+\eta \hat{p}-\hat{K}, \\
& \hat{\hat{K}}=\hat{p}+b+\beta \hat{K}+(1-\beta) \hat{L}-\hat{K},
\end{aligned}
$$

In this model, the wage rate is considered a rough indicator of welfare. It will grow at the same rate as the marginal productivity of labour. The driving forces behind the latter are the rate of technical progress and the growth rate of the capital-labour ratio, which is denoted by k:

$$
\hat{w}-\hat{p}=b+\beta \hat{k}
$$


Since the rate of technical progress is given, the remaining question is whether a low income elasticity of export demand hinders rapid growth of the capital-labour ratio by restricting the importation of capital goods. The growth rates for the long-term equilibrium growth path are of crucial interest in this respect. Solving equation (5') for the growth rate of the terms of trade and inserting the result into equation (4') yields:

$$
\hat{\hat{K}}=\frac{\rho \hat{Z}-(1+\eta) b-(1+\eta)(1-\beta) \varepsilon}{-\eta}+\frac{-\beta+\eta(1-\beta)}{-\eta} \hat{K},
$$

As shown in Figure 1, this is a linear differential equation with a negative slope. A price elasticity of export demand, which is more negative than minus one, is a sufficient condition for drawing the equation with a positive intercept. However, although negative vertical and horizontal intercepts and a resulting negative long-run growth rate seem to be possible as well, they have to be excluded in the absence of depreciation rates because they would require negative exports and savings in this simple model. The arrows imply that there is a stable point for the capital accumulation rate.

\section{FIGURE 1 OVER HERE}

The next step is to set the growth rate of the rate of capital accumulation equal to zero and to solve for the growth rate of the capital-labour ratio, $k=K / L$ :

$$
\hat{k}=\frac{[\rho \hat{Z}-\varepsilon-(1+\eta) b]}{[-\eta(1-\beta)+\beta]},
$$

Inserting this solution into the equation determining the change in the terms of trade and in equation (8'), respectively, yields the following solutions for the terms of trade and real wages:

$$
\hat{p}=\frac{[(\rho \hat{Z}-\varepsilon)(1-\beta)-b]}{[-\eta(1-\beta)+\beta]},
$$




$$
\hat{w}-\hat{p}=\frac{[(\rho \hat{Z}-\varepsilon) \beta-\eta b]}{[-\eta(1-\beta)+\beta]},
$$

The numerators of equations (9) to (11) consist of two terms, the first of which reflects the "engine of growth" part from the export demand function: the growth rate of world income multiplied by the income elasticity of export demand. The product of the trade partners' income and income elasticity is the driving force on the demand side behind the terms of trade, behind the capital-labour ratio, and behind the wage rate. Hence, this part represents the intentions of Prebisch, Singer, and Myrdal (1957, p.60). The second part, on the other hand, captures the handmaiden part (see Kravis 1970). This term supports the view that technical progress leads to an increase in exports via decreased prices if exports are price elastic. Consequently, the causality runs from growth to exports, opposite to what the engine of growth supporters propose. Our model contains both parts. Note, however, that the handmaiden part drops out if a country has no technical progress whereas the engine part remains in the model unless the income elasticity is zero.

The direct effect of technical progress is to decrease production costs and to reduce the terms of trade as can be read off equation (10). The question then arises whether this will cause exports and investments to rise or fall. Assuming exports are price-elastic, there will be an increase in exports and investments as well as in the capital-labour ratio in equation (9). If exports are price-inelastic, however, technical progress leads to a fall in the terms of trade and thereby has a negative impact on the growth rate of the capital-labour ratio. Considering the growth rate of real wages, it is obvious that technical progress has not only a direct but also an indirect effect on this variable. The latter effect is due to changes in the capital-labour ratio induced by technical progress. The direct effect outweighs the indirect one so that technical progress always has a positive impact on real wages.

Summing up, technical progress has a negative effect on the terms of trade while having a positive impact on the real wages. Because of these opposite influences, the terms of trade are no indicator of development as far as technical progress is concerned.

Focusing on the income elasticity of export demand and on the growth rate of the trade partners' income, the following conclusions are reached. The higher the income elasticity the higher the growth of export demand for any growth rate of world income and the higher the growth rate of capital imports in equation (9). The latter aspect causes real wages in equation (11) to grow at a higher rate and, therefore, the growth rate of the terms of trade is driven up 
as well. A higher growth rate of income in the trade partners' countries will lead to an increase in exports. Yet, the critical point is whether the change in income multiplied by the income elasticity, $\rho \hat{Z}$, exceeds the population growth rate, $\varepsilon$. This difference governs the growth rate of the capital-labour ratio in equation (9). If the income elasticity of export demand is low and the population growth rate is high, the effect on the growth rates concerning the terms of trade, the capital-labour ratio, and real wages will be negative.

In conclusion, the terms of trade will fall on condition that the rate of technical progress is not exceeded by a large difference between the export growth rate and the population growth rate in equation (10). The growth rates of the capital-labour ratio and the real-wage rate may be negative because of low income and price elasticities. Now all variables included in the solutions for the growth rate of the terms of trade and the one of real wages exert the same influences on these growth rates. Hence, with respect to income elasticity and trade partners' income growth, the terms of trade are an indicator of economic development because they drive up both, real wages and the terms of trade.

\section{Comparison with the Results of the Solow Growth Model}

The Prebisch-Singer thesis poses the task of presenting trade conditions which result in a slower growth rate for the main economic indicators of welfare than in the Solow model. Considering a Solow model with a production function like equation (1), the real wage, the capital-labour ratio, and per capita income grow at the same rate, $b /(1-\beta)$. In the model examined above, this result can be obtained by means of taking into account two special cases. First, equation (11) can be written in the form:

$$
\hat{w}-\hat{p}=\frac{b}{(1-\beta)}\left\{1-\frac{\beta}{[\eta(1-\beta)]}\right\}+\frac{(\rho \hat{Z}-\varepsilon) \beta}{[-\eta(1-\beta)+\beta]},
$$

For any value of $\rho \hat{Z}$, it holds that $\hat{w}-\hat{p}=b /(1-\beta)$ when considering $\eta$ approaching minus infinity. That is known as the small country case in neoclassical models. Second, it can be shown that

$$
\hat{w}-\hat{p}=b /(1-\beta) \text { and } \quad \hat{p}=0 \text {, both if } \rho=1 .
$$

This conclusion holds on condition that the world taken as a whole grows at the rate $\hat{Z}=\varepsilon+b /(1-\beta)$ just like a closed economy in the Solow model. Then, the engine of 
growth, $\hat{Z}-\varepsilon$, has the same effect as the handmaiden part, $b /(1-\beta)$, and therefore, the growth rate coincides with that of the Solow model.

Figure 2 presents $\hat{w}-\hat{p}$ as a function of $\rho$ for different values of $\eta$. The vertical intercept increases with the price elasticity of exports. The slope, on the other hand, is less steep the more price-elastic exports are (see Ziesemer, 1995, for the derivation of the intercepts and slopes).

\section{FIGURE 2 OVER HERE}

Due to equation $\left(11^{\prime}\right)$, there is one straight line for each value of $\eta$, being equal to $b /(1-\beta)$ at $\rho=1$. The horizontal line represents the small country case with the price elasticity being equal to minus infinity. It shows that in this case exports constitute no constraint to growth, a conclusion that is in line with traditional neoclassical thinking. Figure 2 reveals that the capital importing economy grows at a lower rate than in Solow's model if the income elasticity is lower than one. For income elasticities greater than one, the economy grows faster than predicted by the Solow model. These conclusions do not hold for a price elasticity of minus infinity, since this is the small country case.

In view of the interplay between the growth rate of the terms of trade and the income elasticity of export demand, a similar graph is drawn in figure 3. For a derivation of the vertical intercept and of the slope see Ziesemer (1995). The less price-elastic exports the steeper the slope and the more negative the vertical intercept. For income elasticities smaller than one, the growth rate of the terms of trade fall and real wages grow at a slower rate than in the Solow model. There is, thus, a close relationship between the latter two variables. The driving force behind both of them is the income elasticity of export demand. The effect of the latter is reinforced by a lower price elasticity of export demand. The obvious corollary is that of a high price elasticity weakening the impact of the income elasticity of export demand on the developments of real wages and the terms of trade. As in the previous graph, the relationship is drawn for $\hat{Z}=\varepsilon+b /(1-\beta)$ and alternative estimates for the price elasticity. To summarize, the price and income elasticities of export demand are crucial determinants for a developing country's growth prospects.

\section{FIGURE 3 OVER HERE}


Our interpretation of the Prebisch-Singer Thesis yields a model in which the importation of capital goods and low (high) elasticities of export demand contribute to explaining the slow (fast) growth of developing countries. Such a presentation is in line with the intentions of Prebisch, Singer, and Myrdal. The question now arises whether these price and income elasticities are indeed low. That issue is taken up in the following chapters. In order to test the empirical relevance of low elasticities of export demand, regressions will be run. Yet, data of the variables appearing in those two equations need to be collected. We carry out these estimations for Brazil.

Again, we would like to point out the simplifying assumptions we have made: absence of domestic capital goods, imported consumption goods, foreign debt, and unbalanced trade. None of these assumptions holds true for Brazil as can easily be seen by examining the World Development Indicators. ${ }^{2}$ Whether or not the abstraction is too strong will be revealed by the econometric work. After all, the widely used Solow growth model is a special case of our model, which ignores imported inputs and the exports used to pay for them. Furthermore, other models on which the estimation of export demand income and price elasticities are based use a similar export demand function but do not make use of a growth model for the supply side as we do. Integrating all of these aspects in a fully-fledged model would require the estimation of even more parameters with a low number of observations. Therefore, it is not necessarily a drawback to use this simple model. In a model including domestic capital goods, these would have to grow at a rate that is proportional to that of foreign capital goods in order to avoid running too much into decreasing returns to the accumulation of one of them only. Absence of debt is dealt with by using the investment/GDP ratio rather than the savings ratio. Khan and Knight (1988), and Esfahani (1991) also assume all imports to be inputs. For the steady state solutions it can be shown that these aspects do not matter. But they matter for the dynamics outside the steady state. By implication, the closer a country is to its steady state the less these omissions matter.

The equations estimated below are obtained as follows. First, we insert the export and the production function into equations (4) and (5), respectively, and add the depreciation rate to

\footnotetext{
${ }^{2}$ For Brazil, Gross fixed Capital formation (GFCF) is about twice as large as total imports. For 1995 (but not for other years), we can calculate from the WDI that production of machinery and transport equipment is about \$US 38.1 billion. This is roughly 25\% of GFCF. However, 8.8 billion of the 38.1 billion are exported, leaving approximately 29 billion for domestic investment. On the other hand, 21 billion are imported according to the UN International Trade Statistics Yearbook, indicating that about $42 \%$ of machinery and transport equipment is imported - provided it is not re-exported. Unfortunately, it seems impossible to construct separate stocks of domestic and foreign capital without having similar information for other items and periods of GFCF than just machinery and transport as of 1995.
} 
each function. Moreover, we add a constant term $B$ to the export demand function ${ }^{3}$ and allow for non-constant returns to scale in the production function by replacing (1- $\beta$ ) by $\alpha$. Note that we do not use the marginal productivity conditions stated above. Finally, we multiply an error term $U$ to the production function and an error term $V$ to the export function, yielding modified versions of equations (4) and (5):

$d K / K+\delta=s p U A e^{b t} K^{\beta-1} L^{\alpha}$,

$d K / K+\delta=V B Z^{\rho} p^{\eta+1} K^{-1}$,

Taking natural logs and solving for the $\ln$ of the left-hand side and of $p$ gives:

$$
\begin{aligned}
& \ln (\hat{K}+\delta)=\frac{-\ln B}{\eta}+\ln A \frac{\eta+1}{\eta}+\frac{\eta+1}{\eta} \ln s+\frac{b(\eta+1)}{\eta} t+\frac{\beta \eta+\beta-\eta}{\eta} \ln K \\
& +\frac{\alpha(\eta+1)}{\eta} \ln L+\frac{-\rho}{\eta} \ln Z+\frac{\eta+1}{\eta} \ln U-\frac{1}{\eta} \ln V,
\end{aligned}
$$

$$
\ln p=\frac{\ln A-\ln B}{\eta}+\frac{1}{\eta} \ln s+\frac{b}{\eta} t+\frac{\beta}{\eta} \ln K+\frac{\alpha}{\eta} \ln L-\frac{\rho}{\eta} \ln Z+\frac{1}{\eta}(\ln U-\ln V)
$$

Once one equation is estimated, it is obvious that all parameters can be identified. Note that this system holds for both, the steady state and the transition path. We estimate the equations as a simultaneous system.

\section{The data}

We decided to carry out the empirical estimation for Brazil because it is a developing country, which at the same time belongs to the richer economies among the less developed ones, and, maybe therefore, all data are available. In order to estimate the system, time series for the savings or investment/GDP ratio, capital, trade partners' income and employment are required. The data for gross fixed capital formation as percentage of (GDP minus depreciation) are taken from the World Development Indicators 2004 and represent investment. We make use of this figure instead of the savings ratio in order to account for that part of investment financed by foreign debt, which is ignored by our model. The data for

\footnotetext{
${ }^{3}$ A separate estimate of the export demand function in terms of growth rates yields a growth rate of B which is insignificantly different from zero.
} 
capital are constructed by cumulating Gross Fixed Capital Formation after subtraction of the data for depreciation, starting from an initial value determined according to the formula ${ }^{4}$

$$
K_{0}=\frac{I_{1}}{\left(\hat{K}_{1}+\delta\right)}
$$

Depreciation is assumed to be $3.7 \%$ of capital for all periods because this is the average value of available figures in earlier national accounts data. For $I_{1}$ we use the gross fixed capital formation as of 1970. The initial growth rate of the capital stock in the above formula is assumed to be .1 , which corresponds to the order of magnitude of the growth rates of GDP and employment in those years. With the capital stock obtained in this way we can take growth rates as log differences and add the rate of depreciation to get the dependent variable of equation (12a). The employment data are taken from the ILO website. The time series starts in 1972 but values for the years 1974, 1975, 1980, 1991, 1994, 2000, 2001 are missing. We do not try to interpolate them because in an earlier attempt we found that different ways of doing so removed the unit root processes in the time series. Trade partner's income is taken to be world income since Brazil is trading with all countries in the world. The terms of trade are calculated as 'Exports as capacity to import' divided by 'exports of goods and services', both in terms of constant local currency units.

\section{Econometric methods and estimation results for the system of equations}

Econometric methods have been developed traditionally for stationary variables and more recently for variables which are integrated of order one, I(1). Before discussing the methods we check whether the time series follow unit root processes and determine the order of integration of the variables. Testing for unit roots suffers from the fact that these tests have been designed for a large number of observations whereas we deal with only a few observations. Hence, the tests have low explanatory power. For world income the ADF test does not reject the unit root hypothesis. All other variables do not follow unit root processes. Consequently, we use equations (12a) and (12b) with only one modification: we replace $\ln Z$ by $d(\ln Z) * t$. The latter version of the variable does not have a unit root. So we can use equations (12a) and (12b) in its current form.

\footnotetext{
${ }^{4}$ See Verspagen (1995) for an extensive explanation.
} 
The system has three important properties. First, there are constraints on the coefficients, generating a non-linear problem of estimation. Second, both equations of the system contain the random terms from the production function and the export function and therefore the residuals of the two equations will not be independent. These two properties together suggest using the seemingly unrelated regression (SUR) method. Third, equation (12a) is a differential equation. Residuals have a positive impact on the dependent variable, enhancing the capital variable on the right-hand side in the next period. As this is a stock variable, the effect is permanent. In other words, the residuals have an impact on all future variables of capital and the regressors are not exogenous although they are predetermined (see Davidson and Mackinnon 2004, chapter 3.2). As this would bias the estimates, we use the generalized method of moments (GMM-HAC with heteroscedasticity and autocorrelation correction of the coefficient standard deviations) including all right-hand side variables and lagged variables of capital as instruments. We present only the GMM estimate.

\section{TABLE 1 OVER HERE}

The regression and the implied values for the parameters of the model are reported in Table 1. The over-identifying constraints for the additional instruments are significant since the product of the J-statistic and the number of observations is low enough. The income elasticity of export demand (0.19) is at the lower end of the range of earlier estimates and the price elasticity (-1.86) is larger in absolute terms than in previous studies (see Table 2 for a comparison). The time trend representing technical progress is significant. This is not the case, however, if merely a low number of instruments is used. The sum of the elasticities of production is smaller than unity and indicates decreasing returns to scale. As shown above, the Solow growth model is a special case of our model in which the price elasticity should equal minus infinity. This would require $c(2)=1$. Given the high significance of the value around 0.5 it is clear that the alternative (to our model) hypothesis of the Solow model will be rejected by an F-test. Our efforts to correct for autocorrelation (see Mutz and Ziesemer 2005) drive the results towards a price elasticity of minus 3.8, constant returns to scale with an elasticity of production for capital of .29 and for labour of .29, an income elasticity of .25, and TFP growth towards .345\%, which corresponds to a rate of labour saving technical change of 1\%. One might speculate that with explicit recognition of imports and debt the income elasticity and perhaps other variables may get different values. 
TABLE 2 OVER HERE

\section{Conclusion}

We have estimated the model for its non-steady-state version. Note that the assumption of perfect competition was not used in the estimated parts of the model. The results clearly demonstrate that income and price elasticities of export demand may be important for the growth of Brazil in the period we have considered. The Solow model, which is a special case of our model, is clearly rejected due to the high significance of the coefficient for investment. The Wald test rejects the hypothesis that the coefficient is unity with an error probability of zero. In spite of a potential omitted variable bias, the simultaneous estimates for income and price elasticity of export demand, for elasticities of production and scale economies, as well as for total factor productivity growth are quite realistic and underpin the relevance of the arguments at the heart of Prebisch-Singer arguments. 


\section{References}

Bahmani-Oskooee, M. and M. Miteza. 2002. Do nominal devaluations lead to real devaluations in LDCs? Economics Letters, 74, pp. 385-391.

Bairam, E.I. 1993. Income Elasticities of Exports and Imports: A Re-Examination of the Empirical Evidence, Applied Economics, 25, pp. 71-74.

Bardhan, P.K. and S. Lewis. 1970. Models of Growth with Imported Inputs, Economica, November, p. 373.

Basu, K. 1991. The International Debt Problem, Credit Rationing and Loan Pushing: Theory and Experience. Princeton Studies in International Finance, No.70, October.

Darity, W. Jr. (1986), Did the Commercial Banks Push Loans on the LDCs? In: Michael Claudon (ed.), World Debt Crisis: International Lending on Trial, Cambridge, Mass., Ballinger, 199-225.

Eaton, J. and M. Gersovitz. 1981. Debt with potential Repudiation: Theoretical and Empirical Analysis, Review of Economic Studies, Vol.48, 289-309.

Fullerton, T.M., Jr, W.C. Sawyer and R.L. Sprinkle. 1999. Latin American Trade Elasticities, Journal of Economics and Finance, Vol. 23, no. 2, pp. 143-156.

Houthakker, H.S. and S.P. Magee. 1969. Income and Price Elasticities in World Trade, Review of Economics and Statistics, Vol. LI, no. 2, pp. 111-125.

Kravis, I.B. 1970. Trade as a Handmaiden of Growth, Economic Journal, December, pp. 850-872.

Mutz, C. and T. Ziesemer. 2005. Simultaneous Estimation of Income and Price Elasticities of Export Demand, Scale Economies and Total Factor Productivity Growth for Brazil, MERIT Research Memorandum. http://www.merit.unimaas.nl/publications/rmpdf/2005/rm2005-004.pdf .

Myrdal, G. 1957. Economic theory and underdeveloped regions. German edition. Fischer, Frankfurt 1957.

Perkins, D.H., S.Radelet, D.R.Snodgrass, M.Gillis, M.Roemer. 2001. Economics of Development, $5^{\text {th }}$ ed., New York and London: Norton. 
Prebisch, R. 1950. The Economic Development of Latin America and its Principal Problems, Economic Bulletin for Latin America, Vol. VII, No. 1, February 1962 (reprinted), pp.1-22.

1959. Commercial Policy in the Underdeveloped Countries, The American Economic Review, Vol. XL IX/2, May, pp. 251-273.

Singer, H.W. 1950. The Distribution of Gains between the Investing and Borrowing Countries, American Economic Review, vol.40, No.2.

Solow, R.M. 1956. A Contribution to the Theory of Economic Growth, Quarterly Journal of Economics, LXX, 1, February 1956, pp. 65-94.

Verspagen, B. 1995. R\&D and Productivity: A Broad Cross-Section Cross-Country Look, Journal of Productivity Analysis, July 1995, v. 6, iss. 2, pp. 117-35

Ziesemer, T. 1995. Economic Development and Endogenous Terms-of-Trade Determination: Review and Reinterpretation of the Prebisch-Singer Thesis, UNCTAD Review 1995, pp. 17-33.

1995b , Growth with Imported Capital Goods, Limited Export Demand and Foreign Debt, Journal of Macroeconomics, Vol. 17, No.1, 31-53. 1997. From Loan Pushing to Credit Rationing: Interest Shocks in a Model by Basu. Journal of Institutional and Theoretical Economics, September 1997, 569-78.

1998. A Prebisch-Singer Growth Model and the Debt Crises", in: "DEVELOPMENT

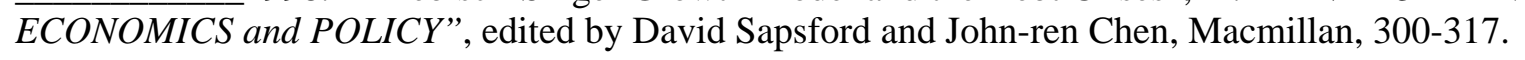




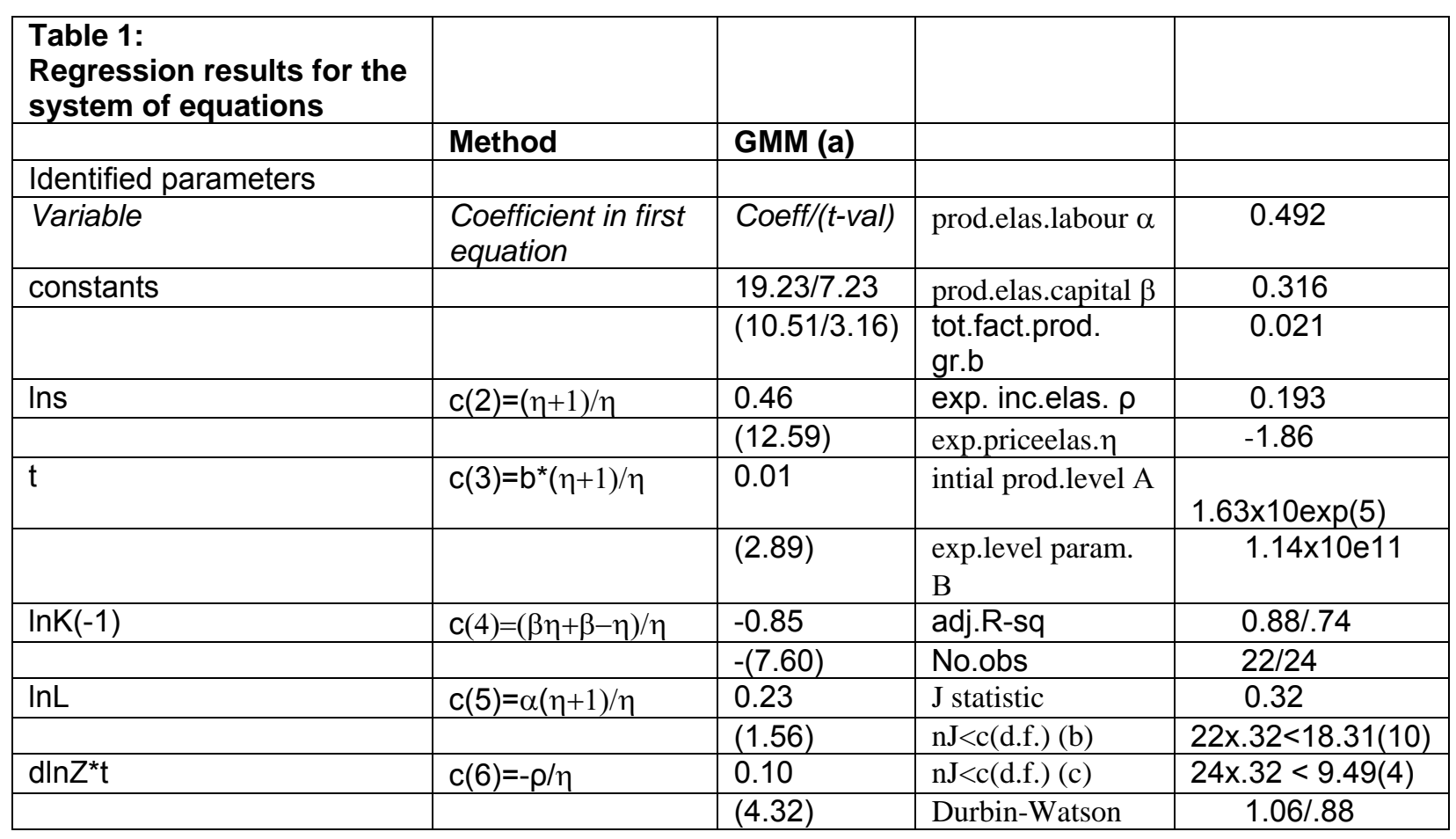

(a) Instruments: regressors, plus $\operatorname{lnk}(-2)$ to $(-7)$ in the first equation and none in the second.

(b) for the first equation at the $5 \%$; degrees of freedom is number of constraints, which is 4 , plus number of lagged instruments.

(c) for the second equation at the $5 \%$;degrees of freedom is number of constraints, which is 4 , plus number of lagged instruments. 
Table 2: $\quad$ Overview of income and price elasticities of export demand for Brazil

\begin{tabular}{|l|l|l|l|l|l|l|}
\hline Year & Author & Period & y & pm/pd & pm & pd \\
\hline 1969 & $\begin{array}{l}\text { Houthakker, } \\
\text { Magee }\end{array}$ & $1951-1966$ & 0,34 & $-0,39$ & & \\
\hline 1976 & Lemgruber & $1965-1974$ & $1,97^{*}$ & $-0,41^{*}$ & & \\
\hline 1984 & Aggarwal & $1969-1978$ & 0,253 & $-1,23^{*}$ & & \\
\hline 1986 & $\begin{array}{l}\text { Bahmani- } \\
\text { Oskooee }\end{array}$ & $1974: 1-1980: 4$ & 0,007 & $-0,151$ & & \\
\hline 1988 & Zini & $1970: 1-1986: 3$ & 0,690 & & $-0,171^{*}$ & 0,131 \\
\hline 1992 & $\begin{array}{l}\text { Faini, Pritchett, } \\
\text { Clavijo }\end{array}$ & $1967-1983$ & $0,60^{*}$ & $-1,51^{*}$ & & \\
\hline 1993 & Bairam & $1964-1985$ & 3,93 & & & \\
\hline 1995 & Reinhart & $1970-1991$ & 2,447 & $-0,148$ & & \\
\hline
\end{tabular}

y: foreign market income

pm: import unit value index

pd: domestic producer price or wholesale index

*: significance at $5 \%$ level

Source: Bairam (1988), Fullerton et al. 1999, Houthakker and Magee (1969), Reinhart (1995). 
Figure 1: $\quad$ A Graphical Presentation of Equation (4")

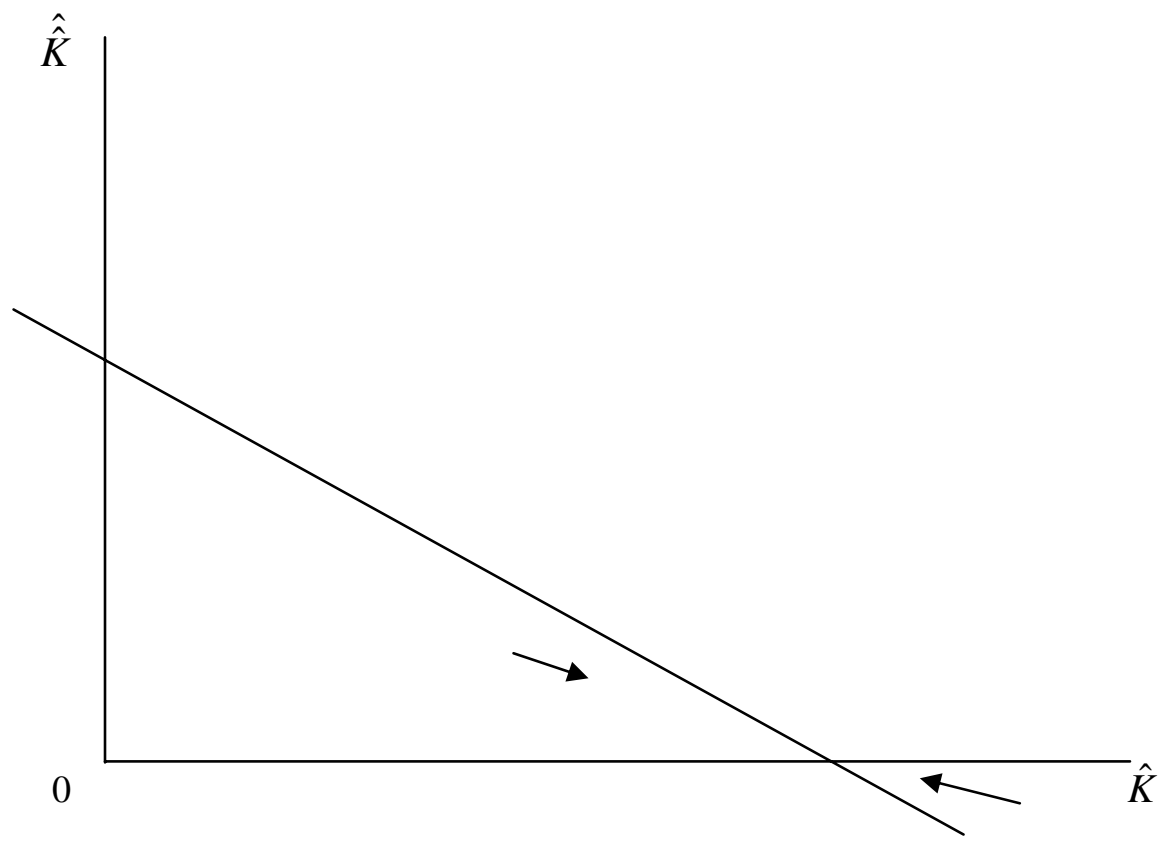


Figure 2: The Relationship between the Growth Rate of Real Wages and the Income Elasticity of Exports (for various Values of the Price Elasticity)

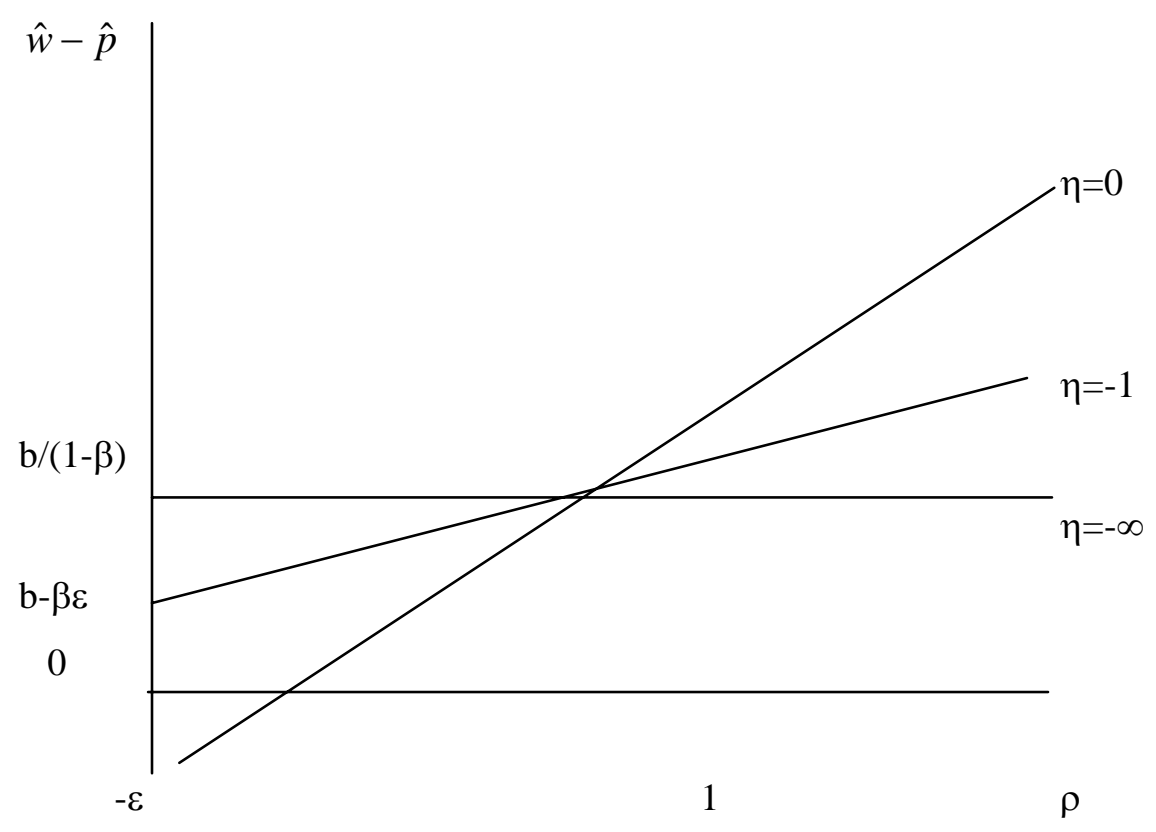


Figure 3: The Relationship between the Growth Rate of the Terms of Trade and the Income Elasticity of Export Demand (for various Values of the Price Elasticity)

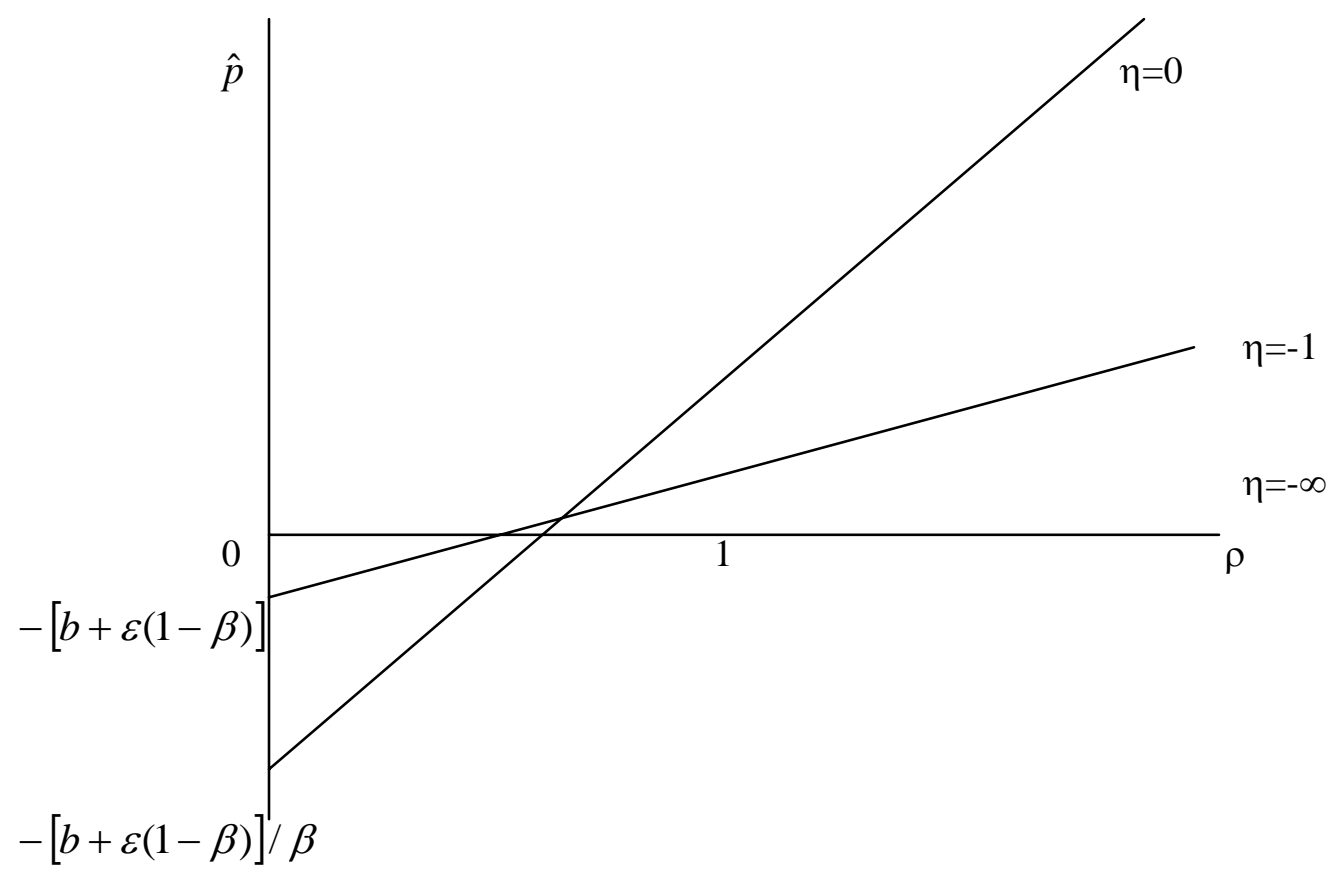

